\title{
THE LEGALITIES OF REVOKING UNIVERSITY DEGREES FOR MISCONDUCT: RECOMMENDATIONS FOR AUSTRALIAN UNIVERSITIES
}

\author{
PNINA LEVINE* AND MICHELLE EVANS ${ }^{* *}$
}

The revocation of university degrees, whilst once unheard of, has been increasingly employed by Australian universities in the wake of high-profile cheating scandals. Yet, to date, there is only one reported Australian case, Re La Trobe University; Ex Parte Hazan in which a student has challenged a university's decision to revoke a degree. However, this case does not comprehensively address the legal issues surrounding decisions to revoke degrees. This paper therefore seeks to provide Australian universities with some clarity with respect to these issues, elucidating the source of the power of universities to revoke degrees, and the circumstances in which this power can be exercised. It does so through a review of English and United States case law, an analysis of accepted Australian administrative law principles, and an examination of university legislation in Australia.

\section{INTRODUCTION}

The subject of revoking university degrees recently gained attention in Australia following the 'MyMaster' cheating scandal which resulted in several Australian universities revoking the degrees ${ }^{1}$ of graduates who had engaged in purchasing assignments during their degree studies. ${ }^{2}$ The consequences of

\footnotetext{
* $\quad$ Associate Lecturer, Curtin Law School, Curtin University.

** Associate Professor, Curtin Law School, Curtin University.

The authors would like to thank Professor Ian Freckleton QC, Professor Philip Evans, Professor Aviva Freilich, Dr Narrelle Morris and three anonymous reviewers for their comments on earlier drafts of this article.

1 This article adopts a broad interpretation of the term 'degree', using it to refer to any award made by a university to a student at the completion of a course of study. It refers to both graduate and post-graduate degrees, including masters and doctoral degrees, certificates, diplomas, and bachelor degrees.

2 The 'MyMaster' cheating scandal related to the purchase by international students of their assignments from the MyMaster website for credit towards their degrees at major Australian universities. It has been reported that Macquarie University revoked the degrees of two students involved in this scandal: see Lisa Visentin, 'Macquarie University Revokes Degrees For Students Caught Buying Essays in MyMaster Cheating Racket', The Sydney Morning Herald (online), 28 May $2015<$ http://www.smh.com.au/national/
} 
revocation are unsurprisingly severe for a graduate. If a degree is revoked, the graduate's career options, chances of enrolment in future study, and their reputation and livelihood can suffer substantial damage. ${ }^{3}$ Scandals involving the revocation of degrees by universities can also cause serious reputational damage to universities, and compromise the integrity of their degrees.

Due to these cheating scandals, universities have become increasingly vigilant about discouraging, detecting and dealing with instances of misconduct. In these circumstances, it is likely that universities will be faced more frequently with the question of whether to revoke the degrees of their graduates and will need to be more mindful of the legal issues and consequences relating to such a course of action. However, the laws surrounding the power of universities to revoke degrees, including the grounds on which a university graduate may challenge the revocation of their degree, are largely untested in an Australian context and require clarification. There is some academic literature and case law on this issue in the United States. However, there is minimal academic literature in Australia, and only one reported case decided in 1993 by a University Visitor, being Re La Trobe University; Ex Parte Hazan ('Hazan'). ${ }^{4}$

The decision in Hazan does not address many of the legal issues surrounding revocation. In fact, the case raises more questions about the legalities surrounding revocation than it answers. For example, what power does a university actually have to revoke a degree? If it does have such power, is this power unconstrained? More specifically, what sort of academic misconduct is sufficient to justify the revocation of a degree? Further, does the imposition of such a penalty apply only to academic matters, or could it extend to other disciplinary matters involving social misconduct? Given the severity of the consequences to a graduate that may result from the revocation of his or her degree, should all of the grounds upon which revocation may be justified be defined and listed in university statutes? Finally, what are the procedures that should be followed by a university before making a revocation decision? For example, what standard of procedural fairness is required to be afforded to a graduate facing the penalty of revocation? This article seeks to address these questions, which are largely untested in an Australian context.

education/macquarie-university-revokes-degrees-for-students-caught-buying-essays-in-mymastercheating-racket-20150527-ghba3z.html>. The University of Wollongong also reportedly revoked one degree: see Brianna Parkins and Lisa Visentin, 'University of Wollongong Student Stripped of Degree After Being Caught in MyMaster Essay-Cheating Racket', The Sydney Morning Herald (online), 1 June $2015<\mathrm{http}$ //www.smh.com.au/national/education/university-of-wollongong-student-stripped-of-degreeafter-being-caught-in-mymaster-essaycheating-racket-20150531-ghdr7n.html>.

3 In many situations, financial detriment may also be incurred as a result of the graduate having paid out a large sum for his or her tuition and living expenses leading up to the conferral of the degree.

4 [1993] 1 VR 7. This lack of case law is most likely attributable to the fact that revocation has only recently been seriously considered as an option by Australian universities. The rise of contract cheating websites has made it easy for students to cheat, whilst presenting the outsourcing of assignment writing as a legitimate option for time-poor students: see, eg, Michelle Evans and Pnina Levine, "'We Need to Talk About Your Assignment": The Requirements of Procedural Fairness When Academic Misconduct is First Suspected' (2016) 42 Monash University Law Review 339, 354-5. Additionally, as universities move towards electronic submission of assignments and, consequently, their longer retention, it is easier for universities to revisit past assignments if they suspect academic misconduct such as plagiarism. 


\section{RE LA TROBE UNIVERSITY; EX PARTE HAZAN}

Hazan was heard in the Supreme Court of Victoria by the Governor of Victoria, Reverend Doctor JD McCaughey, in his capacity as University Visitor. ${ }^{5}$ The case involved a challenge by Mr Hazan of La Trobe University Council's decision to revoke his Bachelor of Arts degree, and to terminate his current enrolment in a Diploma of Education. The decision to revoke Hazan's degree was based upon a recommendation by a Committee of Inquiry, appointed by the University Council, to advise the Council on whether Hazan's degree should be revoked. In making its recommendation, the Committee of Inquiry relied on two findings. Firstly, that Hazan had falsely claimed that he held a diploma from a Talmudical College in London. Secondly, that he had forged documents purporting to be from this College certifying that he had successfully completed a rabbinical course there, in order to gain admission into the Bachelor of Arts degree at La Trobe University and to obtain credit towards this degree. The grounds of Hazan's challenge included: that the University had no power to revoke his degree, and that there had been a failure by the University to afford Hazan procedural fairness. ${ }^{6}$

Regarding the issue of whether the University had the power to revoke a degree, the Visitor noted that there 'was some debate' as to whether, under the La Trobe University Act 1964 (Vic), the University Council could revoke a degree after it had been conferred. ${ }^{7}$ However, in his decision, the Visitor did not examine the University's Act or any of its rules or regulations to determine whether the University in fact had the power of revocation. Instead, the Visitor accepted that the University had this power, stating that 'in the case of proven fraud, I have no doubt as to the power of the University Council to do so, nor as to the propriety of doing so provided that procedural fairness (due process) is observed' ${ }^{8}$

In making his decision, the Visitor referred to several judgments by overseas courts. These judgments had been relied upon by the Committee of Inquiry as authority for its view that the University had the power to revoke Hazan's degree in circumstances of fraud. Specifically, the Visitor referred to the English case of $R v$ The Chancellor, Masters, and Scholars of the University of Cambridge

5 The office of the University Visitor dates back to the early $14^{\text {th }}$ century English custom whereby the founder of a charitable foundation (for instance, a university college) would appoint a Visitor to ensure that it was governed according to the founder's requirements. Most Australian university statutes originally provided for the appointment of the State Governor as the University Visitor. However, with the exception of Western Australia, the role of the University Visitor has now been removed or amended in all Australian states: see Debelle J's discussion of the Visitor's jurisdiction in the case of Re petition to Dame Roma Mitchell AC DBE (1992) 57 SASR 573; see also David M Price and Peregrine W F Whalley, 'The University Visitor and University Governance' (1996) 18 Journal of Higher Education Policy and Management 45; Patty Kamvounias and Sally Varnham, 'Legal Challenges to University Decisions Affecting Students' (2010) 34 Melbourne University Law Review 140, 147-50.

6 There was no challenge to the Visitor's jurisdiction to hear and decide the case: Hazan [1993] 1 VR 7, 13 (McCaughey).

$7 \quad$ Ibid 12.

8 Ibid. 
('Bentley's Case') $)^{9}$ and the United States case of Waliga v Board of Trustees of Kent State University ('Waliga') ${ }^{10}$ as legal authorities for this power. He quoted from the decision in Waliga, a case heard by the Supreme Court of Ohio, in which the Court stated that:

The English common law provides precedential rules of decision ... Modern courts have also traditionally refused to interfere with fundamental university functions, such as the granting and withdrawing of academic degrees, except to require that good cause be shown and that a fair hearing procedure be made available. ${ }^{11}$

The Visitor further cited Judge Bailey Brown of the United States Court of Appeals in the case of Crook $v$ Baker to emphasise that the award of a degree constitutes a university's 'certifi[cation] to the world that the recipient has fulfilled the university's requirements, and this certification continues until the degree is revoked'. ${ }^{12}$

Unfortunately, neither of the judicial quotations relied upon by the Visitor in the Hazan case sufficiently explain the power of a university to revoke a degree. Instead, they serve as more of an assertion as to the courts' long-established deference to university processes, and as a rationalisation of the revocation of degrees by universities. ${ }^{13}$

Given the Visitor's finding that the University's decision to revoke Hazan's degree on the grounds of fraud was not 'arbitrary or capricious' ${ }^{14}$ and due to his concluding that procedural fairness had been afforded to Hazan, the Visitor was not prepared to 'interfere' in the University's decisions in accordance with the courts' 'traditional refusal' to do so.

\section{JUDICIAL REVIEW OF UNIVERSITY DECISIONS}

A discussion of the power of Australian universities to revoke degrees and the limitations on this power, if any, assumes the willingness of an Australian court to involve itself in reviewing a decision by a university to revoke the degree of a graduate. ${ }^{15}$ Kamvounias and Varnham's consideration of Australian case law

9 (1723) 2 Ld Raym 1334; 92 ER 370. There are three reported versions of this case: (1723) 2 Ld Raym 1334; 92 ER 370 considers whether the University had the authority to revoke Bentley's degrees; (1722) 1 Strange 557; 93 ER 698 concerns the contempt charge; and (1723) Fort 202; 92 ER 818 considers the remedy of mandamus. The facts described here are found from reading these three versions together.

10488 NE 2d 850 (Ohio, 1986).

11 Ibid 852-3 (Wise J), quoted in Hazan [1993] 1 VR 7, 12.

12813 F $2 d 88,93$ (6 $6^{\text {th }}$ Cir, 1987).

13 It is noted that the reason for this lack of explanation may have been due to the Visitor not being strictly bound by legal precedent, instead applying the 'law of the house' to cases within his or her jurisdiction: see Robert J Sadler, 'The University Visitor in Australia: Murdoch University v Bloom' (1980) 7 Monash University Law Review 59, 64; see also Robert J Sadler, 'The University Visitor: Visitatorial Precedent and Procedure in Australia' (1981) 7 University of Tasmania Law Review 2, 8.

14 Crookv Baker, 813 F 2d 88, 100-1 (Bailey Brown J) (6 ${ }^{\text {th }}$ Cir, 1987), quoted in Hazan [1993] 1 VR 7, 13 (McCaughey).

15 This article focuses on judicial review of university decisions to revoke degrees. However, the authors acknowledge that graduates of state or territory universities may also make a complaint to a state or territory ombudsman (called the 'Parliamentary Commissioner' in Western Australia), or to the Overseas 
concerning university students provides an analysis of the willingness of Australian courts to involve themselves in university matters. ${ }^{16}$

Kamvounias and Varnham observe that Australian courts are generally reluctant to interfere with university decisions involving academic judgment, such as decisions in relation to the awarding of marks, applications for credit for prior study, applications regarding course content and assessment standards, and applications concerning academic progress. ${ }^{17}$ However, when it comes to disciplinary matters relating to academic and non-academic misconduct by students, courts are more willing to intervene and review the relevant decisions. ${ }^{18}$ Indeed, in such cases, at least insofar as public universities are concerned, ${ }^{19}$ the courts have 'consistently and universally insisted on strict adherence to accepted administrative law principles'. ${ }^{20}$

Yet, there is an additional impediment that a graduate seeking judicial review of a university's decision to revoke their degree may need to overcome. If a graduate is seeking judicial review of a university's revocation decision under judicial review legislation (as distinct from under common law), ${ }^{21}$ he or she must establish that the decision was made 'under an enactment' ${ }^{22}$ for it to be a reviewable decision. This was established in the case of Griffith University $v$ Tang ('Tang') in which Tang sought legislative judicial review of a university decision to exclude her from a PhD program due to alleged academic misconduct in the form of fabricating data and results from her experiments. ${ }^{23}$ The High Court decided that Tang was not entitled to a review of the decision under the

Students Ombudsman for graduates of private universities. In general, an ombudsman has limited powers, and can only give a non-binding opinion as to the merits and/or legality of the decision, which the university may choose not to follow. See Ombudsman Act 1989 (ACT); Ombudsman Act 1974 (NSW); Ombudsman Act 2009 (NT); Ombudsman Act 2001 (Qld); Ombudsman Act 1972 (SA); Ombudsman Act 1978 (Tas); Ombudsman Act 1973 (Vic); and Parliamentary Commissioner Act 1971 (WA). The Overseas Students Ombudsman was established in 2011 under s 19ZI(1) of the Ombudsman Act 1976 (Cth), but can only investigate complaints by overseas students against private education providers: at $\mathrm{s}$ 19ZJ(3). Given the non-binding nature of the Ombudsman's powers, it is unlikely to be a viable option for a graduate who has had their degree revoked.

16 Kamvounias and Varnham, 'Legal Challenges to University Decisions Affecting Students', above n 5. For an analysis of the willingness of American courts to intervene in university decision making, see, eg, Jayme L Butcher, 'MIT v Yoo: Revocation of Academic Degrees for Non-academic Reasons' (2001) 51 Case Western Reserve Law Review 749.

17 Kamvounias and Varnham, 'Legal Challenges to University Decisions Affecting Students', above n 5, 160-5. However, even in relation to purely academic decisions, Kamvounias and Varnham note that if the student's challenge is to the decision-making process as distinct from the decision itself, the courts will intervene as 'substance is immune from review but process is not': at 164 .

18 Ibid 165-9.

19 Private universities, whilst not the primary focus of this article, are discussed later in this section.

20 Kamvounias and Varnham, 'Legal Challenges to University Decisions Affecting Students', above n 5, $166,169$.

21 The existing state and territory judicial review legislation is as follows: Administrative Decisions (Judicial Review) Act 1989 (ACT); Judicial Review Act 1991 (Qld); Judicial Review Act 2000 (Tas); Administrative Law Act 1978 (Vic).

22 See Administrative Decisions (Judicial Review) Act 1989 (ACT) s 2, Dictionary (definition of 'decision to which this Act applies'); Judicial Review Act 1991 (Qld) s 4; Judicial Review Act 2000 (Tas) s 4.

23 (2005) 221 CLR 99. This case is discussed in detail in Patty Kamvounias and Sally Varnham, 'Doctoral Dreams Destroyed: Does Griffith University v Tang Spell the End of Judicial Review of Australian University Decisions?' (2005) 10(1) Australia \& New Zealand Journal of Law \& Education 5. 
Judicial Review Act 1991 (Qld). This was primarily because according to a majority of the Court, the decision was not made 'under an enactment', such as the Griffith University Act 1998 (Qld), as required by section 4(a) of the Judicial Review Act 1991 (Qld) but rather, it was made under a university policy. The High Court's decision called into question whether a student could seek judicial review of university decisions at all, given that many decisions affecting students are arguably made under policies. However, it is now common for universities to provide for the power to revoke in either their primary statute or delegated legislation, or for this power to be implied by statute, as is outlined later in this article. Therefore, it is very likely that a university's decision to revoke a degree would generally be regarded as being made under an enactment.

In any event, a graduate seeking judicial review of a decision to revoke their degree may arguably seek judicial review under the common law, thereby negating the need for the decision to be made 'under an enactment'. ${ }^{24}$ In New South Wales, South Australia, Western Australia and the Northern Territory where there is no judicial review legislation, common law judicial review may be the only judicial review option available to a graduate who has had his or her degree revoked..$^{25}$ However, the process of common law judicial review can be lengthy, expensive and technically complex, and is only advisable as a last resort. ${ }^{26}$

Given the apparent willingness of courts to review decisions by universities to revoke degrees, this article focuses on the grounds upon which such a revocation decision could be legally challenged under either common law or legislative judicial review. However, even if a university's decision to revoke a degree is not amenable to judicial review, making administrative remedies unavailable to an affected graduate, a court may still be prepared to provide alternative relief to the graduate on grounds such as a failure by the university to afford procedural fairness or that the decision amounts to a breach of contract. Indeed, the courts have shown a willingness to intervene in disputes involving private clubs or associations, particularly with respect to procedural fairness, in relation to disciplinary matters, or if a person's livelihood may be affected. ${ }^{27}$ Therefore, it is suggested that the recommendations made in this article will also assist any university whose decisions to revoke may not be subject to judicial

24 The ability to seek review under judicial review legislation at the same time as common law review is discussed in Kamvounias and Varnham, 'Doctoral Dreams Destroyed', above n 23, 15.

25 A graduate would be most likely to seek the prerogative writ of certiorari which would have the effect of quashing the university's decision to revoke a degree: see Craig v South Australia (1995) 184 CLR 163, 179 (Brennan, Deane, Toohey, Gaudron and McHugh JJ).

26 Regarding the complexity of prerogative writs, see Robin Creyke and John McMillan, Control of Government Action: Text, Cases and Commentary (LexisNexis Butterworths, $2^{\text {nd }}$ ed, 2009) 1084, quoting K C Davies, Administrative Law Treatise (K C Davies Publishing, 1958) [388].

27 This is discussed in some detail in Creyke and McMillan, above $\mathrm{n}$ 26, 129. Cases cited by Creyke and McMillan in support of the courts' willingness to review matters involving private clubs and associations include: Dixon v Australian Society of Accountants (1989) 87 ACTR 1; Australian Football League v Carlton Football Club Ltd [1998] 2 VR 546; Goodwin v Vietnam Veterans Motor Cycle Club Australia NSW Chapter Inc (2008) 72 NSWLR 224. 
review, such as private universities, ${ }^{28}$ in relation to their decision-making. The position taken by United States commentators is similar and supports this view. ${ }^{29}$

This article will identify the possible legal sources of an Australian university's power to revoke degrees. In most cases this will be by virtue of an express or implied statutory power, making the decision to revoke generally amenable to judicial review. It will further discuss any substantive and procedural limitations on this power, namely the grounds upon which a university's decision to revoke a degree can, or should be able to be, legally challenged. This analysis will provide clarity and guidance to Australian universities when they are faced with the question of whether, and how, to revoke the degree of a graduate. It will also provide assistance to Australian courts when judicial review of these decisions is sought.

\section{THE POWER OF AUSTRALIAN UNIVERSITIES TO REVOKE DEGREES}

As explained above, the University Visitor in Hazan accepted that a university has the power to revoke a degree in 'the case of proven fraud'.$^{30}$ The Visitor cited Bentley's Case, Waliga and Crook v Baker as authorities for this power. However, the Visitor did not elaborate on the source, or sources, of this power in his decision. Through an examination of university statutes, principles of statutory interpretation and case law, this section will identify and analyse the various sources of a university's power to revoke a degree and discuss their application in an Australian context.

\section{A Express Statutory Power}

Increasingly, Australian university statutes and delegated legislation (namely rules, regulations, or by-laws made under university statutes) can be found to include an express power of revocation. Although there was no such express power to revoke degrees in the La Trobe University statutes when Hazan was decided, this power is now provided for in the Degrees, Diplomas \& Other Awards Statute 2009 (Vic) ('Degrees Statute') made under the La Trobe University Act 2009 (Vic) ('La Trobe Act'). Section 10(3) of the La Trobe Act

28 The susceptibility of decisions of private universities to judicial review is slightly more complex than those of public universities because '[w]here an institution is incorporated under the Commonwealth Corporations Act or other relevant legislation [with possible] ... statutory support in the form of enabling legislation ... the relationship between the student and university does not find its effect in administrative law but in the private law of contract': Bruce Lindsay, 'Complexity and Ambiguity in University Law: Negotiating the Legal Terrain of Student Challenges to University Decisions' (2007) 12(2) Australian \& New Zealand Journal of Law \& Education 7, 8. It is noted that there are only a few private universities in Australia including, for example, the University of Notre Dame, Bond University and Torrens University Australia.

29 See, eg, Butcher, above n 16, 766-8; Mary Ann Connell and Donna Gurley, 'The Right of Educational Institutions to Withhold or Revoke Academic Degrees' (2005) 32 Journal of College and University Law 51,68 .

30 Hazan [1993] 1 VR 7, 12 (McCaughey). 
states that, '[i]f the university statutes so provide, the Council may revoke any degree conferred or other award granted by the University, whenever conferred or granted'. The University has indeed provided for this in section 9(1)(a) of the Degrees Statute. This states that the Academic Board, after consideration of a report from a Committee of Inquiry, may 'find that the degree, diploma or other award to which the report relates was improperly obtained, and revoke the degree, diploma or other award'. Further examples of an express power to revoke in a university statute include the University of Melbourne Statute 2016 (Vic) regulation 14(3) which states that the Council may revoke a degree that has been obtained in error, fraudulently, or due to student misconduct. ${ }^{31}$

However, what is the situation if a university's statutes or delegated legislation are silent in relation to the university's power to revoke degrees? Does the university still have the power to revoke a degree? An analysis of case law coming out of the United Kingdom and the United States suggests that it does.

\section{B Implied Statutory Power}

The $18^{\text {th }}$ century English Court of Chancery decision, Bentley's Case, has been applied by the courts in the United States as authority for the inherent power of a university to revoke a degree that it has conferred. The first reported case challenging a revocation in the United States was the case of Waliga. In Waliga, the Supreme Court of Ohio cited Bentley's Case when it held 'that a college or University acting through its board of trustees does have the inherent authority to revoke an improperly awarded degree where (1) good cause such as fraud, deceit, or error is shown, and (2) the degree holder is afforded a fair hearing at which he can present evidence and protect his interests' ${ }^{32}$

The case of Waliga involved a challenge to the revocation of the degrees of two graduates of Kent State University. The Board of Trustees of the University revoked the Bachelor of Arts degrees of Waliga and Taylor after finding 28 errors in Waliga's academic transcript, and 34 in Taylor's academic transcript. These included grades being recorded for subjects that they had withdrawn from, or had never enrolled in, or that were not offered by the University during the relevant study period. Notably, these errors were only detected some 15 years after Waliga and Taylor had graduated and had been awarded their degrees. Before taking any action to revoke the two degrees, the University invited Waliga and Taylor to present their arguments against such a decision before the relevant Council (although they were informed that they were not entitled to have legal representation at this hearing of their case). Waliga and Taylor did not attend at the Council hearing but subsequently applied to the Portage County Common Pleas Court seeking to prevent the University from revoking their degrees. This Court held that without express statutory authority, the Board of

31 See University of Melbourne Statute 2016 (Vic) regs 14(3)(a)-(c). Other examples of an express power to revoke being found in university legislation include: Academic Misconduct Rules 2016 (WA) r 1.3; General Misconduct Rules 2016 (WA) r 1.3; Academic Record Fraud Rules 2010 (WA) r 1.3, made pursuant to Statute No 10 - Student Discipline 2010 (WA) ('Statute 10') enacted under the Curtin University of Technology Act 1966 (WA) s 34.

32488 NE 2d 850, 852 (Wise J) (Ohio, 1986) (emphasis added). 
Trustees of Kent State University had no power to revoke degrees previously awarded. The Court of Appeals ${ }^{33}$ affirmed the lower court's judgment. ${ }^{34}$

However, on appeal, the Supreme Court of Ohio reversed the Court of Appeals' decision. In the Supreme Court's view, the Kent State University had statutory authority (as well as a common law power as explained below) to revoke degrees under the Ohio Revised Code. ${ }^{35}$ This was because the Code gave authority to the University to confer degrees and to 'do all things necessary for the proper maintenance and successful and continuous operation of such universities' ${ }^{36}$ The Supreme Court considered it obvious that the revocation of a degree by a university for 'good cause such as fraud, deceit, or error' ${ }^{37}$ was necessary for the proper operation of the university. This was so given that:

Academic degrees are a university's certification to the world at large of the recipient's educational achievement and fulfillment of the institution's standards. To hold that a university may never withdraw a degree, effectively requires the university to continue making a false certification to the public at large of the accomplishment of persons who in fact lack the very qualifications that are certified. Such a holding would undermine public confidence in the integrity of degrees, call academic standards into question, and harm those who rely on the certification which the degree represents. ${ }^{38}$

However, the proviso was that the degree-holder be 'afforded a fair hearing at which he can present evidence and protect his interest'.$^{39}$

It is common for university statutes in Australia to contain similar provisions to the Ohio Revised Code referred to in Waliga. More specifically, they generally provide for the university to do anything that is reasonably necessary to perform its functions. For example, section 6(3)(c) of the University of New South Wales Act 1989 (NSW) states that:

the University has such general and ancillary functions as may be necessary or convenient for enabling or assisting the University to promote the object and interests of the University, or as may complement or be incidental to the promotion of the object and interests of the University. ${ }^{40}$

It is most likely, as supported by the United States case law discussed above, that the power to revoke degrees is 'necessary or convenient' to enable a university to carry out its functions including to confer degrees and for its general good governance. In this way, under the terms of their statutes, Australian universities will generally have an implied statutory power to revoke degrees.

However, even if an Australian university statute does not explicitly state that the university has the power to do anything that is necessary to perform its

\footnotetext{
33 'Appeals' (plural) is accurate. In Australia, 'Appeal' (singular) would be used instead.

34 Waliga v Board of Trustees at Kent State University, (Ohio Ct App, No 1444, 30 November 1984).

353341 Ohio Rev Cod Ann (West 2016).

36 Waliga, 488 NE 2d 850, 852 (Wise J) (Ohio, 1986), citing 3341 Ohio Rev Cod Ann $§ 3341.04$ (West 2016).

37 Waliga, 488 NE 2d 850, 852 (Wise J) (Ohio, 1986).

38 Ibid.

39 Ibid.

40 See also University of Queensland Act 1998 (Qld) s 6(1); University of South Australia Act 1990 (SA) s 5(1)(g); University of Melbourne Act 2009 (Vic) s 6(3)(h); Curtin University of Technology Act 1966 (WA) s 7(2); and Murdoch University Act 1973 (WA) s 6(2).
} 
functions, it is likely that the university will still have the implied statutory authority to revoke a degree conferred by it. Indeed, in Waliga, the Supreme Court of Ohio stated that even if the Code had not expressly provided for the University to 'do all things necessary for the proper maintenance and successful and continuous operation of such universities', actions in furtherance of this end would still be within the University's implied authority, unless prohibited by legislation. Specifically, the Supreme Court explained that, '[i]n the event that a degree is procured by fraud, or a degree is awarded erroneously, it is certainly within the implied authority of the University to revoke it' ${ }^{41}$ The Supreme Court continued on to explain that, "[t]he power to confer degrees necessarily implies the power to revoke degrees erroneously granted'. ${ }^{42}$

This was also the view taken by the District Court for the Western District of Virginia in Goodreau $v$ Rector and Visitors of the University of Virginia ('Goodreau'). ${ }^{43}$ This case concerned the revocation of Goodreau's Bachelor of Science degree by the University of Virginia. The basis for the revocation was that he had stolen more than $\$ 1500$ in University funds while president and treasurer of a university club. The theft was discovered the year after Goodreau had graduated. Goodreau pleaded guilty to the criminal offence of 'misdemeanor embezzlement'. However, Goodreau's degree was not revoked until approximately six years after his graduation when he decided to apply to undertake a Master of Business Administration and requested that a notation on his transcript with the words 'enrollment discontinued' be removed. Although the 'Honor Committee' ${ }^{44}$ had initially recommended some six years earlier that Goodreau's degree should be revoked, this recommendation was not actioned due to an oversight by the Dean.

Goodreau brought an action against the Rector, the Board of Visitors of the University and other members of the University's administration and the Honor Committee (together, 'the University') as a result of the revocation of his degree. He challenged the revocation on the basis that, among other things, the Board of Visitors lacked the power to revoke his degree. The University applied for summary judgment in relation to Goodreau's claims - that is, for the court to decide in favour of the University by dismissing the matter before it proceeded to trial.

Although the University did not succeed in its application for summary judgment in relation to many of Goodreau's claims, it did succeed in refuting Goodreau's claim that the Board of Visitors lacked the power to revoke the degree. Similar to the Court in Waliga, District Judge Moon of the Virginia District Court found that although this power was not expressly provided for in the Code of Virginia ${ }^{45}$ such a power was implied. This was because according to Virginia case law, the University 'ha[d] not only the powers expressly conferred upon it, but it also ha[d] the implied power to do whatever [was] reasonably

\footnotetext{
41 Waliga, 488 NE 2d 850, 852 (Wise J) (Ohio, 1986).

42 Ibid.

$43 \quad 116$ F Supp 2d 694 (WD Va, 2000).

44 United States spelling has been retained to be consistent with the decision.

4523 Va Code Ann (West 2017).
} 
necessary to effectuate the powers expressly granted' ${ }^{46}$ In the view of District Judge Moon, the power to revoke degrees (for good cause and after due process) was 'reasonably necessary' to effect the power conferred on the Board of Visitors by the Code to confer degrees and to 'regulate the government and discipline of the students'. ${ }^{47}$

The Court of Appeals in the United States decision of Hand $v$ Matchett ${ }^{48}$ took a similar approach, confirming that the body empowered to confer a degree could also revoke the degree, even in the absence of an explicit power to revoke in the statute. The Court commented that ' $[t]$ he plain language of the statute gives the Regents exclusive power to confer degrees. Implicit in that power must be the authority to revoke degrees'. ${ }^{49}$

In summary, where an Australian university statute provides for the award of degrees, but does not mention an explicit power to revoke them, it is likely that a court would imply the power to revoke them. This power would be necessarily implied in the university's statutory power to do all things necessary for the proper governance of the university, or in the university's power to confer degrees. Further support for such an implied statutory power can be found in Australian legislation pertaining to the interpretation of statutes. ${ }^{50}$

\section{Non-statutory Sources of Power}

\section{Common Law Power}

In addition to being cited in support of a university's inherent power to revoke degrees, Bentley's Case is also the earliest authority for the common law position that universities have the power to revoke degrees. In Bentley's Case, the English Court of Chancery, Kings Bench noted that the body or persons who had the power to confer a degree had the power to revoke it. The Court stated that, 'the chancellor, masters and scholars used to confer degrees, and to suspend them, and remove persons from them' ${ }^{51}$ Subsequent United States courts have cited Bentley's Case as common law authority for the power of universities to revoke degrees after conferral. ${ }^{52}$ The common law power of universities to revoke degrees, as provided for in Bentley's Case, would also carry authoritative weight in Australia. Indeed, it was this authority that the Visitor in Hazan relied upon in

46 Goodreau, 116 F Supp 2d 694, 703 (Moon DCJ) (WD Va, 2000), citing Batcheller v Commonwealth, 10 SE 2d 529, 535 (Gregory J) (Va, 1940).

47 Goodreau, 116 F Supp 2d 694, 703 (Moon DCJ) (WD Va, 2000), citing 23 Va Code Ann § 23-76 (West 2017).

$48 \quad 957$ F 2 d 791 (10 $10^{\text {th }}$ Cir, 1992).

49 Ibid 794 (Barrett J).

50 See, eg, Interpretation Act 1984 (WA) s 50(2)(c) which provides that where a statute confers power 'to approve any person, matter, or thing, such power includes power to withdraw approval thereof'. See also Acts Interpretation Act 1931 (Tas) s 22A which provides that: 'A power in an Act to grant a right includes a power exercisable in a like manner and subject to the same consent and conditions, if any, to vary or revoke the right'; and Acts Interpretation Act 1954 (Qld) s 24AA(a) which states that '[i]f an Act authorises or requires the making of an instrument or decision - (a) the power includes power to amend or repeal the instrument or decision'.

51 Bentley's Case (1723) 2 Ld Raym 1334, 1341; 92 ER 370, 374.

52 See, eg, Waliga, 488 NE 2d 850, 852 (Wise J) (Ohio, 1986). 
reaching his decision that La Trobe University had the power to revoke Hazan's degree.

\section{Contractual Power}

In addition to having a statutory or common law basis, it can be further argued that a university's power to revoke degrees has a basis in contract. Academic commentators have suggested that there is a contractual relationship, albeit an ambiguous one, between the university and the student. ${ }^{53}$ However, there is no specific Australian precedent confirming the existence of such a contractual relationship, at least in respect of the relationship between a student and a public university. ${ }^{54}$ This is because most litigation between students and such universities occurs in the context of other areas of law including administrative law, consumer law, and equal opportunity law..$^{55}$

Even if a contractual relationship could be established between a student and a university on the proper completion of the enrolment process, the terms of the contract would be difficult to determine. That is, it would be necessary to determine whether university legislation or other statutory instruments giving the university the power to revoke a degree constitute valid contractual terms and if not, the decision to revoke will be a matter of administrative law..$^{56}$

\section{Summary}

In summary, there is no doubt that Australian universities do have the power to revoke degrees they have conferred. This power is derived from several sources. Firstly, many university statutes contain an express statutory power to revoke degrees. Secondly, universities also have an implied statutory power to revoke degrees. This is derived from either a general statutory power to do all things necessary to govern the university, or a statutory power to confer degrees. Thirdly, universities have the power to revoke degrees at common law. Each of these options arguably involves public decision-making by universities, and therefore operates within the parameters of administrative law. However, there may also be a private law aspect to a university's power to revoke, which is distinct from the operation of administrative law, namely a contractual relationship between a university and a student (albeit currently unconfirmed by

53 See, eg, the commentators cited by Francine Rochford, 'The Contract Between the University and the Student' in Sally Varnham, Patty Kamvounias and Joan Squelch (eds), Higher Education and the Law (Federation Press, 2015) 82, 82 n 1, including:

David Palfreyman, 'Phelps ... Clark ... and Now Rycotewood? Disappointment Damages for Breach of the Contract to Educate' (2003) 15 Education and the Law 237. In the United States, see Ross v Creighton University, 957 F 2d 410 ( $7^{\text {th }}$ Cir 1992); Alec Samuels, 'The Student and the Law' (1973) 12 Journal of the Society of Public Teachers of Law 252.

54 See, eg, Xv University of Western Sydney (No 3) [2013] NSWSC 1329, [43]-[44]. In relation to private universities, there is authority that the source of student rights 'is primarily contractual': see Orr v Bond University (unreported QSC, No 2337/96, Dowsett J, 3 April 1996) 6 cited in Patty Kamvounias, 'Students and the Australian Consumer Law' in Sally Varnham, Patty Kamvounias and Joan Squelch (eds), Higher Education and the Law (Federation Press, 2015) 92, 93 n 13, 93-4.

55 Rochford, above n 53, 85.

56 Ibid 88. 
Australian precedent), a breach of which may entitle the university to terminate the contract by revoking the degree.

What is less certain, however, is the scope of the power of universities to revoke degrees. That is, exactly when a university can, and should, revoke a degree and what the procedural requirements are when making such a decision and acting upon it. Subject to the university's power to revoke not being limited in any way by statute, what is the extent to which an Australian court will, or should, make a determination as to whether the revocation of a graduate's degree by a university is justified? Is revocation such a serious step that it can only be justified in the most extreme circumstances - as a 'last resort'? If permitted, what are the procedural requirements that must be satisfied before the revocation of a degree can take place? These questions will be addressed in the following section.

\section{LEGAL LIMITATIONS ON THE POWER TO REVOKE A DEGREE}

As explained above, Australian courts are generally willing to intervene and review university decisions relating to disciplinary matters. The extent of judicial intervention is, as generally stated by Ashley $\mathbf{J}$ in the Victorian Supreme Court in the case of Hoang $v$ Monash University: ${ }^{57}$

the proceeding before [the court] is not a proceeding which enables a re-hearing of the matter which was heard by the discipline committee. No such appeal is possible, to this court or to any other court ... This court is solely concerned with whether or not there was some procedural unfairness in the proceeding below, or whether the decision that was reached was so far out of kilter with the material before the committee that it was shown to be quite unreasonable. ${ }^{58}$

Thus, if a court is satisfied that a university has the power to make the decision to revoke a degree, it will only review the substantive and procedural nature of the university's decision on specific legal grounds. ${ }^{59} \mathrm{~A}$ review of Bentley's Case, and subsequent United States' case law, together with an analysis

57 [2001] VSC 376. This case involved a student challenging a decision by a university to exclude him for harassing and intimidating a female staff member.

58 Hoang $v$ Monash University [2001] VSC 376, [9], quoted in Kamvounias and Varnham, 'Legal Challenges to University Decisions Affecting Students', above n 5, 170-1. It is noted that this approach is similar to the position taken by the courts in the United States. See, eg, Crook v Baker, 813 F 2d 88, 100 (Bailey Brown J) (6 ${ }^{\text {th }}$ Cir, 1987).

59 We have distinguished between procedural and substantive grounds of review (the former relating to the procedures involved in reaching the decision, and the latter relating to the decision itself), to give better clarity and guidance to university administrators. This approach is similar to that taken by the United States courts (as relied upon by the University Visitor in Hazan). As explained above, the Supreme Court of Ohio in Waliga considered the power of a university to revoke an 'improperly awarded degree' to have both substantive limitations, in that it can only be exercised where 'good cause such as fraud, deceit or error is shown' and procedural limitations, in that 'the degree-holder is [to be] afforded a fair hearing at which he can present evidence and protect his interest': Waliga, 488 NE 2d 850, 852 (Wise J) (Ohio, 1986). The Court in Crook v Baker referred to these limitations in terms of 'substantive due process' and 'procedural due process', with the Court finding that Crook had been afforded both by the University: 813 F 2d 88 (6 ${ }^{\text {th }}$ Cir, 1987). 
of accepted Australian administrative law principles, assists in identifying these grounds.

There are several grounds on which the substantive nature of a university's disciplinary decision to revoke a degree could be judicially reviewed. These include that relating to the reasonableness of the decision (to determine whether the decision is, as referred to above, 'so far out of kilter with the material before the committee that it [is] shown to be quite unreasonable' ${ }^{\prime}$ ). Additionally, a court could review the substantive nature of the decision to determine whether the university failed to take relevant considerations into account; ${ }^{61}$ took irrelevant considerations into account; ${ }^{62}$ acted for an improper purpose; ${ }^{63}$ or reached a decision that is not based on logically probative evidence. ${ }^{64}$ There has been judicial recognition that there is an overlap between these latter grounds of review and that of unreasonableness. ${ }^{65}$

Further, there are several grounds on which a university's procedures in making a decision to revoke a degree could be judicially reviewed. These include whether, in making its decision, the university: has followed prescribed statutory procedures; has afforded the graduate 'procedural fairness'; has not unreasonably delayed in revoking the graduate's degree after discovering the misconduct; and whether the university body that has revoked the degree has the jurisdiction to do so.

60 Hoang $v$ Monash University [2001] VSC 376, [9] as referred to above. This statement is reminiscent of 'Wednesbury unreasonableness', which will occur 'if a decision ... is so unreasonable that no reasonable authority could ever have come to it': Associated Provincial Pictures House Ltd $v$ Wednesbury Corporation [1948] 1 KB 223, 230 (Lord Greene MR). Unreasonableness is a ground of review under judicial review statutes: Administrative Decisions (Judicial Review) Act 1989 (ACT) ss 5(1)(e), 5(2)(g); Judicial Review Act 1991 (Qld) ss 20(2)(e), 23(g); Judicial Review Act 2000 (Tas) ss 17(2)(e), 20 (g).

61 This ground of review will be established if the decision-maker has failed to consider a relevant matter, which is significant enough to deprive the applicant of a successful outcome. See, eg, Minister for Aboriginal Affairs v Peko-Wallsend Ltd (1986) 162 CLR 24; see also Administrative Decisions (Judicial Review) Act 1989 (ACT) ss 5 (1)(e), 5(2)(a); Judicial Review Act 1991 (Qld) ss 20(2)(e), 23(b); Judicial Review Act 2000 (Tas) ss 17(2)(e), 20(b).

62 This ground of review will be established if the decision maker has taken into account an irrelevant matter, which is significant enough to deprive the applicant of a successful outcome. See, eg, Murphyores Inc Pty Ltd v Commonwealth (1976) 136 CLR 1; see also Administrative Decisions (Judicial Review) Act 1989 (ACT) ss 5(1)(e), 5(2)(b); Judicial Review Act 1991 (Qld) ss 20(2)(e), 23(a); Judicial Review Act 2000 (Tas) ss $17(2)(e), 20(a)$.

63 The applicant must establish that the decision-maker's purpose for exercising the power was an improper one and not in accordance with the statutory purpose. See, eg, Samrein Pty Ltd v Metropolitan Water Sewerage and Drainage Board (1982) 41 ALR 467; see also Administrative Decisions (Judicial Review) Act 1989 (ACT) ss 5(1)(e), 5(2)(c); Judicial Review Act 1991 (Qld) ss 20(2)(e), 23(c); and Judicial Review Act 2000 (Tas) ss 17(2)(e), 20(c).

64 The decision-maker's decision must be based on 'rationally probative evidence and not ... as a matter of suspicion or speculation': Minister for Immigration and Ethnic Affairs v Pochi (1980) 44 FLR 41, 62 (Deane J). See also Administrative Decisions (Judicial Review) Act 1989 (ACT) s 5(2)(h); Judicial Review Act 1991 (Qld) s 20(2)(h); Judicial Review Act 2000 (Tas) s 17(2)(h).

65 Minister for Immigration and Citizenship v Li (2013) 249 CLR 332, 365 (Hayne, Kiefel and Bell JJ), 350 (French CJ). 


\section{A Substantive Limitations on the Power of Universities to Revoke Degrees}

As noted above, a significant ground on which the substantive nature of a university's decision to revoke the degree of a graduate could be judicially reviewed relates to the unreasonableness of the decision. The original test for the unreasonableness of an administrative decision was referred to as 'Wednesbury unreasonableness'. This test asks whether the decision 'is so unreasonable that no reasonable authority could ever have come to it' ${ }^{66}$ The test was expanded upon by the High Court of Australia in Minister for Immigration and Citizenship $v$ Li. ${ }^{67}$ Hayne, Kiefel and Bell JJ, in a joint judgment, stated that, '[u]nreasonableness is a conclusion which may be applied to a decision which lacks an evident and intelligible justification'. ${ }^{68}$ Their Honours explained that unreasonableness could be ascertained from looking at the overall decision, including if it was unclear as to how, or on what basis, the decision-maker reached the decision. ${ }^{69}$

The willingness of courts to review disciplinary decisions of universities for unreasonableness essentially places a substantive limitation on a university's power to revoke. Specifically, the decision to revoke must not be unreasonable and in this way, it must be justifiable. Given this, it would appear necessary for a university to have some certainty as to when a decision by it to revoke a degree will (or will most likely) be considered to be unreasonable by a court.

There seems to be very little argument, if any, that where a graduate has intentionally not fulfilled the academic criteria required to complete a degree, it is justifiable for a university to withhold or revoke the degree. For example, if the student has committed dishonest conduct such as 'fraud or deceit', or because the degree has been 'awarded erroneously', such as through an error being recorded on the student's transcript. ${ }^{70}$ Indeed, it is understandable that a university would have the power (and possibly even a duty), ${ }^{71}$ to revoke a degree if the graduate acted dishonestly, or did not otherwise satisfy the university's academic requirements for the conferral of the degree.

However, whether a university's power to revoke a degree extends, or should extend, to situations involving all forms of academic misconduct (even conduct that may not be dishonest) is more problematic, with universities and academics similarly divided on this question. Indeed, academics have observed differences in findings and penalties both within and across academic institutions arising from similar factual circumstances as a result of, among other things, the

66 Associated Provincial Pictures House Ltd v Wednesbury Corporation [1948] 1 KB 223, 230 (Lord Greene MR).

67 (2013) 249 CLR 332.

68 Ibid 367.

69 Ibid; see also ibid 379-80 (Gageler J).

70 Connell and Gurley, above n 29, 73.

71 Ibid 57. Cox J, who delivered the judgment of the Court of Appeals of Ohio in Waliga, noted that a university could be acting fraudulently if it were to award a degree without the requirements of the degree being met: see Waliga v Board of Trustees at Kent State University, (Ohio Ct App, No 1444, 30 November 1984) slip opp 12. The failure of a university to revoke a degree could also constitute a contravention of s 18 of the Australian Consumer Law in sch 2 of the Competition and Consumer Act 2010 (Cth). However, this is beyond the scope of this article. 
application of varying definitions of plagiarism. ${ }^{72}$ However, it is arguable that even if the intent behind the specific conduct engaged in by a graduate was not dishonest, revocation of their degree may be reasonable if the graduate of a university 'lack[s] the very qualifications that are certified' ${ }^{73}$

Whether a university's power to revoke the degree of one of its graduates should extend to matters involving non-academic misconduct, referred to in the literature as 'social misconduct', is a very controversial question. ${ }^{74}$ Courts in both the United Kingdom and the United States have decided that universities do have the power to revoke degrees for social misconduct. ${ }^{75}$ Indeed, it was revocation for social misconduct that was relevant in Bentley's Case. In this case, the Vice Chancellor's Court of the University of Cambridge found that Bentley, a graduate of the University, owed money to one of the Masters of the University. When Bentley was later informed of this decision and served with documents to appear to answer this charge, he made critical comments about the process and the Vice Chancellor to the person serving the papers on him. When he subsequently appeared in the Vice Chancellor's Court, he was informed that he 'was guilty of a contempt in speaking opprobrious words of the vicechancellor'. ${ }^{76}$ At a later hearing, to which Bentley was not invited, the Vice Chancellor's Court cancelled his degrees (a Bachelor of Arts, Master of Arts, Bachelor of Divinity and Doctor of Divinity) without affording Bentley the opportunity of a hearing. Although the Court of Chancery acknowledged that the University did have the power to revoke a degree (provided that the body who had the power to confer a degree was the one who revoked it), it granted Bentley a writ of mandamus to compel the University to restore his degrees as a result of a failure to afford Bentley the right to be heard. ${ }^{77}$

In the United States, Goodreau and Yoo v Massachusetts Institute of Technology (' $\left.\mathrm{Yoo}^{\prime}\right)^{78}$ are examples of cases in which the power of universities to revoke their degrees on non-academic grounds was confirmed. As discussed above, in Goodreau, District Judge Moon held that the University had the power to revoke a degree for conduct involving the embezzlement of university funds. His Honour expressly stated that despite the fact that cases such as Waliga and Crook v Baker involved academic misconduct 'as opposed to a disciplinary infraction such as the one involved in the present case' this did 'not weaken their value as authority, for the rationale set forth in those opinions also applies to the

72 Audrey Wolfson Latourette, 'Plagiarism: Legal and Ethical Implications for the University' (2010) 37 Journal of College and University Law 1, 59-74. In Latourette's view, there is a need for academic institutions to have a plagiarism policy which provides for 'unintentional plagiarism' to be treated more leniently than when it is deliberate as well as the consistent application of penalties in similar circumstances: at 71-4.

73 Waliga, 488 NE 2d 850, 852 (Wise J) (Ohio, 1986).

74 See, eg, Connell and Gurley, above n 29; Butcher, above n 16.

75 See, eg, Bentley's Case (1723) 2 Ld Raym 1334; 92 ER 370; Goodreau, 116 F Supp 2d 694 (WD Va, 2000); Yoo v Massachusetts Institute of Technology, 801 NE 2d 324 (Mass App Ct, 2004), cited in Connell and Gurley, above n 29, 62.

76 Bentley's Case (1723) Fort 202, 202; 92 ER 818, 818.

77 Bentley's Case (1723) 2 Ld Raym 1334; 92 ER 370.

78801 NE 2d 324 (Mass App Ct, 2004). 
university's ability to revoke a degree for a violation of the Honor system'.$^{79}$ In this respect, his Honour referred to the comments of the Court in Waliga regarding a degree being a 'certification to the world at large of the recipient's educational achievement and the fulfillment of the institution's standards', ${ }^{80}$ noting that 'the fulfillment of the institution's standards' would require compliance with a university's honour system. ${ }^{81}$

In the subsequent and frequently cited case of $Y o o,{ }^{82}$ the court upheld the revocation of Yoo's degree by the Massachusetts Institute of Technology for a period of five years because of his participation in a fraternity pledge incident the year before his graduation that contributed to a freshman's death. Yoo had allegedly purchased alcohol and instructed the freshman on the quantity that he was expected to drink.

However, the decisions of universities to revoke degrees for non-academic reasons have attracted much academic argument. Many commentators have expressed disagreement with these decisions, and hence with the judicial endorsement of the institutions' authority to revoke for non-academic reasons..$^{83}$ Commentators question, for instance, 'where will the line be drawn' ${ }^{84}$ if revocation for non-academic reasons is allowed. Butcher, for example, poses some relevant questions, ${ }^{85}$ referring to the hypothetical question posed by Batra, '[w] hat if 20 years from now an MIT alumnus is accused of rape by a woman who backs up her charge with DNA evidence - would the university revoke his degree?'\$6 Butcher also asks the following:

May a university revoke the degree of a serial killer because of the shame of having his name tied to the university? What about a politician who acts unethically in public office? Could his alma mater revoke his degree because it disagrees with his actions? This line of questioning raises the troublesome issue of how far a university may go in controlling the conduct of their students - how far may it reach? ${ }^{87}$

Butcher further argues that if a university can revoke a degree for 'arbitrary' reasons, then a student may similarly be able to return their degree and ask for a refund of their tuition fees 'if he or she is dissatisfied with the direction the university decided to head, or is dissatisfied with the result the degree has rendered in the job market' ${ }^{88}$

We suggest that the answer to these questions is actually provided in the decisions of the Courts in Waliga and Goodreau. As explained in these cases

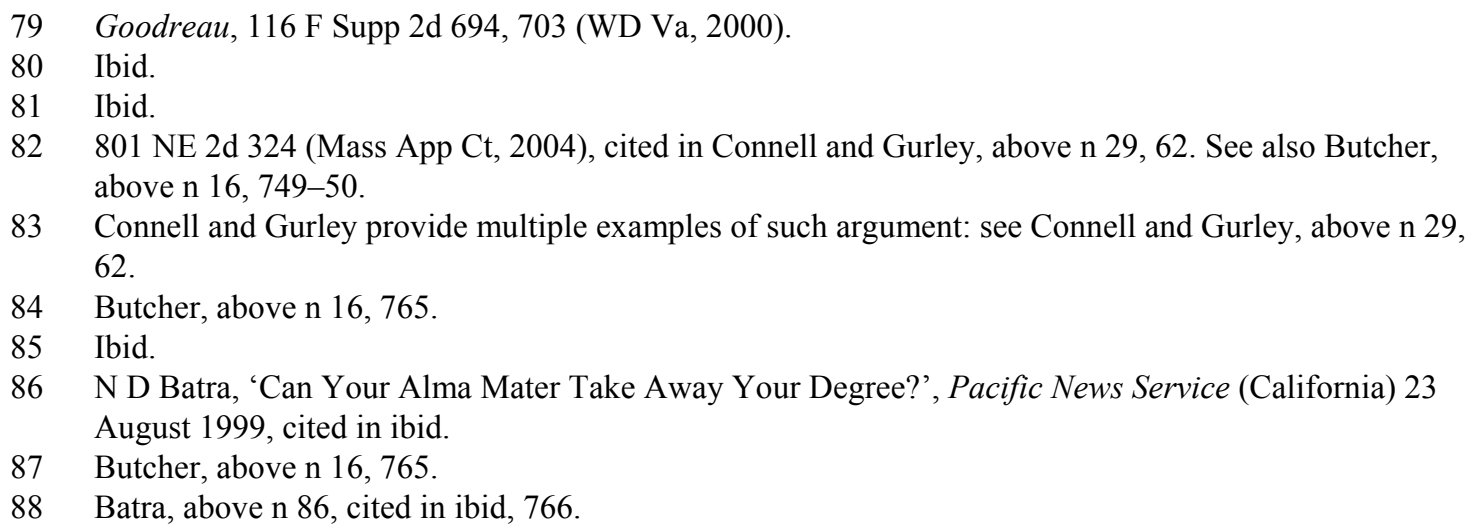


(and cited with approval by the Visitor in the Australian case of Hazan), a degree is, in part, a certification of 'the fulfillment of the institution's standards' ${ }^{89}$ These institutional standards would include a university's academic and non-academic standards. There seems to be little argument, in both relevant case law and academic literature, that a failure by a graduate to satisfy the academic requirements for the conferral of a university degree is generally sufficient grounds for the revocation of that degree. Similar justification could be given for the revocation of a degree by a university where a graduate has failed to satisfy the non-academic requirements for the conferral of a degree, such as a serious contravention of the university's code of conduct. ${ }^{90}$

Yet, once a student has satisfied a university's academic and non-academic requirements for the conferral of a degree, and received the degree, there is no ongoing requirement for them to continue to comply with the university's standards. Consequently, if they subsequently act in a way that is not compliant, there would seem to be no basis on which to justify the revocation of their degree. That is, it could not be said that a graduate of a university who engaged in inappropriate behaviour, inconsistent with the 'institution's standards', sometime subsequent to their being awarded their degree 'lack[s] the very qualifications that are certified' ${ }^{91}$ In this regard, it is argued that although Bentley's Case is authority for the power of a university to revoke a degree in situations where misconduct is committed subsequent to the conferral of a degree, this is inconsistent with the rationale provided for the revocation of degrees in later case law (albeit from the United States). Therefore, it is suggested that in this respect, Bentley's Case should not be followed.

This raises the question of what the non-academic requirements for the conferral of a degree are. They could include compliance with a university's code of conduct. They could also include the requirement not to contravene any laws, such as the criminal law or anti-discrimination law. These requirements may differ across universities depending on the content of their particular statutes, regulations and policies. However, it seems evident that students would need to know the requirements that they have to satisfy in order to obtain their degree. In the same way that the academic prerequisites for the conferral of a degree are expressly provided for and made known to students, the non-academic standards of an institution for the conferral of degree must similarly be clearly set out and made available to students. ${ }^{92} \mathrm{We}$ argue that in circumstances where these standards are not expressly set out, it will be more difficult for a university to prove that they actually are requirements for the conferral of a degree. Therefore,

89 Goodreau, 116 F Supp 2d 694, 703 (WD Va, 2000).

90 This is different to the conclusion drawn by Connell and Gurley who argue that '[o]nce a student graduates, a college or university should not attempt to revoke a degree already conferred for any reason other than error or academic fraud': Connell and Gurley, above n 29, 73.

91 Waliga, 488 NE 2d 850, 852 (Wise J) (Ohio, 1986).

92 This is consistent with Butcher's view. She further posits that the 'list of infractions for which degrees may be revoked should be established ... by neutral parties who can be impartial and unbiased in devising the list of conduct that merits a punishment as severe as revocation of a degree': Butcher, above n 16, 770 . 
a court is more likely to find that the decision to revoke a degree for failure to satisfy them was unreasonable.

It is not common for Australian universities to provide expressly for nonacademic requirements as being prerequisites for the conferral of a degree. ${ }^{93}$ However, they may be implied where the university statutes, regulations or policies expressly provide for the revocation of a degree in circumstances where the student has engaged in such non-academic misconduct. ${ }^{94}$ Nevertheless, it is questionable whether this statement makes it sufficiently clear that good conduct is required for the conferral of a degree. If not, it may need to be more explicit and made available to students at the time of their enrolment, to be able to be relied upon by a university to justify the revocation of a degree.

It is noted that the suggested substantive limitations on a university's power to revoke degrees would not apply to honorary degrees, where the recipient is awarded a degree on the basis of a lifetime of achievement or service to the community. Such degrees are not awarded because recipients have satisfied specific academic and non-academic requirements for the conferral of a degree. Indeed, in the case of honorary degrees, the achievement or service of the recipient is the sole basis for the award of the degree. If this achievement and service is subsequently tainted by the recipient's improper conduct, which may or may not be the subject of criminal charges, the university would be justified in revoking the honorary degree conferred by it. ${ }^{95}$

93 Many universities have student codes of conduct, which set out the rights and responsibilities of students. However, these documents can be aspirational in nature, and are not part of the requirements that a student must satisfy to obtain their degrees. See, eg, Curtin University, 'Student Charter' (27 June 2008) $<$ http://students.curtin.edu.au/rights/documents/StudentCharter.pdf $>$; University of Western Australia, 'Student Charter of Rights and Responsibilities' (1 April 2015) <http://www.student.uwa.edu.au/ experience/charter>; Edith Cowan University, 'Student Charter' <http://intranet.ecu.edu.au/student/mystudies/rules-policy/student-charter $>$. These can be contrasted with the Murdoch University, 'Student Code of Conduct' (3 April 2017) <https://policy.murdoch.edu.au/dotNet/documents/?docid=1819\& LinkedFromInsertedLink=true \&public=true $>$ which, unlike the former charters, contains an express reference to other Murdoch University disciplinary statutes and policies. It expressly states that '[a]ny alleged breach of the Code which falls within the scope of the disciplinary provisions of any University statutes or other regulations will be treated in accordance with those provisions': at 1.

94 Curtin University's General Misconduct Rules 2016 (WA) ('Rules') made pursuant to Statute 102010 (WA) and the Curtin University of Technology Act 1966 (WA) provide a good illustration of rules which provide (or intend to provide) for the revocation of a degree by a university where a student has failed to satisfy specific non-academic requirements for the conferral of a degree. These non-academic requirements are broadly expressed to include contravening a state, federal or territory statute (including a university statute), contravening a lawful direction by a university staff member, infringing the freedom of other students to study or participate in university life, or conduct that is detrimental to the university or its reputation. The Rules specifically provide for 'the rescission or withholding of any award or the withdrawal of credit for any completed unit or both' as constituting a 'Category 2 Penalty' to apply in serious cases of 'General Misconduct' as defined in Statute 102010 (WA): at r 1.3.

95 There are numerous examples of the revocation of honorary degrees. For instance, in 2014 the University of East London revoked an honorary doctorate of letters, conferred by the University in 2007, on entertainer and artist Rolf Harris for his contribution to arts and culture after he was convicted of 12 counts of indecent assault: see Tom Belger, 'Rolf Harris Stripped of Honorary Doctorate', The Guardian (online), 3 July $2014<$ https://www.theguardian.com/uk-news/2014/jul/02/rolf-harris-honorarydoctorate $>$. It was also reported that Bill Cosby, who had received approximately 50 honorary degrees, had approximately 36 of them revoked by the colleges and universities which awarded them after he was charged with sexual assaults: see, Karen Gross, 'What Cosby Scandal Teaches Us', Inside Higher Ed 
Further, the conferral of degrees on convicted criminals, including those who may be serving sentences of imprisonment when undertaking the units for the fulfilment of the degree, ${ }^{96}$ is not inconsistent with the suggested substantive limitations on the power to revoke a degree. If such students have disclosed any criminal conviction in the university admissions process prior to enrolment, and the university has accepted them with knowledge of their record or present incarceration, there would be no basis for the university to subsequently revoke any degree conferred by it. This is provided that the student does not commit any wrongdoing during the course of their study and satisfies the academic and nonacademic requirements for the conferral of the degree. ${ }^{97}$

In summary, if a university has expressly set out the academic and nonacademic requirements for the conferral of a degree and made these requirements available to students on enrolment, and a student fails to satisfy these requirements, then the university would very likely be justified in revoking the degree conferred on that student. In these circumstances, the decision would, or should, be found to be reasonable by an Australian court. However, in circumstances where these requirements are not clearly set out, it will be difficult for the university to prove that a student did not satisfy the requirements for the conferral of a degree. In such cases a court would have more scope to find that the decision to revoke was unreasonable. In any event, any conduct engaged in by a graduate subsequent to receiving their degree is not sufficiently attributable to the requirements of the degree. Hence a court would, or should, find any decision by a university to revoke a graduate's degree for such conduct to be unreasonable.

\section{B Procedural Limitations on the Power of Universities to Revoke Degrees}

A consideration of Australian administrative law, with reference to international case law concerning the revocation of degrees, also highlights the procedures that universities must abide by if any decision to revoke a degree is to survive a legal challenge. It seems evident that universities should ensure that the

(online), 14 January $2016<$ https://www.insidehighered.com/views/2016/01/14/when-should-collegesrevoke-honorary-degree-essay $>$. For further examples of the revocation of honorary degrees, see Ian Freckleton, Scholarly Misconduct: Law, Regulation and Practice (Oxford University Press, 2016). For an example of where a university statute has specifically provided for the revocation of honorary degrees, see University of Melbourne Statute 2016 (Vic) reg 14(4) which sets out the circumstances in which the Council can revoke an honorary degree.

96 For example, Myuran Sukumaran was awarded an associate degree in fine arts by Curtin University whilst imprisoned in Bali, Indonesia for drug trafficking. He completed his degree by correspondence whilst awaiting execution. See Jewel Topsfield, 'Bali Nine Executions: Myuran Sukumaran Awarded Fine Art Degree', The Sydney Morning Herald (online), 27 February $2015<$ http://www.smh.com.au/ world/bali-nine-executions-myuran-sukumaran-awarded-fine-art-degree-20150227-13rakd.html>.

97 Any vetting will generally be left to future employers who may undertake police clearances, or professional bodies (such as the Legal Practice Board of Western Australia) who may view a criminal or disciplinary conviction as indicative that the applicant is not a 'fit and proper person' to enter that profession. 
following specific procedural requirements are satisfied before revoking a degree: 98

- the procedural processes set out in university statutes and policies are followed;

- the graduate is given the opportunity to comprehensively respond to the misconduct allegations before a final decision is made (that is, procedural fairness is afforded to the graduate);

- appropriate steps are taken to investigate any misconduct allegations and to revoke a degree within a reasonable time of being notified of any alleged misconduct; and

- the degree is revoked by the correct body, most usually the body that conferred it.

These requirements are explained further below.

\section{Procedural Processes Set Out in University Statutes and Policies Must Be Followed}

Australian universities are established under legislation as corporate entities. ${ }^{99}$ Consequently, universities, their staff and students are bound by the provisions of this legislation, and must act in accordance with it, as well as any delegated legislation (sometimes referred to as statutes, rules, regulations, or by-laws) made under this legislation. ${ }^{100}$ Thus, if the statute (or delegated legislation) sets out procedures to be followed before a degree can be revoked, then it is essential that those procedures be followed. These procedures could include time limitations, the format of notifications and documentation, and consultation requirements. A failure to follow, or even a departure from, these statutory procedures may amount to what is known as 'procedural ultra vires', ${ }^{101}$ which may justify a legal challenge on the part of a graduate who has had their degree revoked.

98 These limitations are consistent with those set out in the comment by Wood CJ in Harding v University of New South Wales [2002] NSWSC 113, [17], cited in Kamvounias and Varnham, 'Legal Challenges to University Decisions Affecting Students', above n 5, 153.

99 For example, the University of Western Australia was established under the University of Western Australia Act 1911 (WA) s 3 and is a body corporate pursuant to s 6 of the Act. A further example is Curtin University, which was established under Curtin University of Technology Act 1966 (WA) s 5 and is also a body corporate. Curtin University was formerly a college of advanced education. It was reestablished as a university by the Western Australian Institute of Technology Amendment Act 1986 (WA) s 5 by amending Curtin University of Technology Act 1966 (WA) s 5.

100 For a discussion of the establishment of universities and their governance structures, see Joan Squelch, 'The Legal Framework of Higher Education' in Sally Varnham, Patty Kamvounias and Joan Squelch (eds), Higher Education and the Law (Federation Press, 2015) 4.

101 Procedural ultra vires is a specific ground of review under the Judicial Review Acts in the ACT, Queensland and Tasmania: see Administrative Decisions (Judicial Review) Act 1989 (ACT) ss 5(1)(b), 6(1)(b); Judicial Review Act 1991 (Qld) ss 20(2)(b), 21(2)(b); and Judicial Review Act 2000 (Tas) ss $17(2)(b), 18(2)(b)$ respectively. In the states and territories that do not have Judicial Review Acts where the decision to revoke a degree is not made 'under an enactment', a graduate could seek common law judicial review of a decision to revoke their degree on the basis of procedural ultra vires, with similar remedies being available. As discussed earlier in this article, common law judicial review is technical, complicated and protracted. 


\section{The Graduate Must Be Afforded Procedural Fairness}

The common law principle of procedural fairness (also known as "natural justice') requires a decision-maker to inform the person who may be detrimentally affected by a decision of the allegations against them, and to give that person the opportunity of a hearing to refute those allegations. ${ }^{102}$ This requirement is known as 'the hearing rule'. It is a common ground of appeal in administrative law and is a readily cited complaint in student appeals of university decisions. ${ }^{103}$ The decision must also be made by an unbiased decisionmaker. ${ }^{104}$ As early as Bentley's Case, a denial of procedural fairness (then known as natural justice) was successfully argued as a ground of review to challenge the revocation of a degree. ${ }^{105}$

Often, a university statute will state whether procedural fairness should be afforded, and the extent to which it should be afforded. For example, with respect to the hearing rule, the statute may outline the format and timing of the notice that must be given to the student, whether they should be afforded an oral hearing, the required form of submissions (written submissions and/or an oral hearing), and entitlements to legal representation or another support person such as a student guild representative at any hearing. Universities must ensure that they comply with these requirements, to avoid a subsequent successful challenge to the revocation of a degree.

In the absence of explicit statutory provisions about the extent of the hearing prior to the revocation of a degree in a university statute, the opportunities for the graduate to be heard should be generous and extensive. This is due to the very serious consequences for the graduate if their degree is revoked. This appears to be consistent with the position taken by Australian courts in that the more serious the potential consequences of a decision, the more extensive the hearing that is likely to be required. ${ }^{106}$ Further, it is in the best interests of the university, its standing and reputation, to make every effort to avoid any legal challenge to its decisions, particularly those relating to matters as serious as the revocation of degrees.

102 See, eg, FAI Insurances Ltd v Winneke (1982) 151 CLR 342.

103 See, eg, Xv University of Western Sydney [No 3] [2013] NSWSC 1329.

104 This includes actual bias: see, eg, Laws v Australian Broadcasting Tribunal (1990) 170 CLR 70; or when the decision-maker has a reasonable apprehension of bias: see, eg, Livesey $v$ New South Wales Bar Association (1983) 151 CLR 288. This article focuses on the hearing rule because it is likely to arise more often in the context of revocation of degrees and is a more frequently used ground of review. It is noted that in Crook v Baker, $813 \mathrm{~F} 2 \mathrm{~d} 88$ ( $6^{\text {th }} \mathrm{Cir}$, 1987), Crook argued that he had been denied procedural fairness because the ad hoc disciplinary committee, which was comprised of faculty members, was biased. However, this argument was rejected by the Court of Appeals who noted that the Committee's chairperson invited challenges to the members of the Committee at the beginning of the hearing and none were made: at 99-100 (Bailey Brown J).

105 Bentley's Case (1723) 2 Ld Raym 1334; 92 ER 370.

106 See, eg, Johns v Release on Licence Board (1987) 9 NSWLR 103. See also WABZ v Minister for Immigration and Multicultural and Indigenous Affairs (2004) 134 FCR 271 in which French and Lee JJ stated that '[t]he importance of the decision to the applicant's liberty or welfare' was a factor in a decision as to whether to allow legal representation at a tribunal hearing: at 295. A decision to revoke a degree can seriously affect a graduate's welfare because their reputation, livelihood and career can be detrimentally impacted if their degree is revoked. 
It is therefore recommended that a university comply with the following procedural requirements when making a decision as to whether to revoke a degree. The graduate should be:

- told that a decision is going to be made about the revocation of their degree ${ }^{107}$ so they have adequate opportunity to prepare for the hearing and to obtain legal advice beforehand;

- provided with a comprehensive and specific written summary of the allegations against them including all evidence and documentation upon which the revocation decision will be made; ${ }^{108}$

- granted an adequate opportunity to answer the allegations, including being given the opportunity to make written submissions, and also oral submissions at a formal hearing; ${ }^{109}$

- entitled to have legal representation at the hearing; ${ }^{110}$ and

- permitted to cross-examine any witnesses to test the merits of the allegations made against them. ${ }^{111}$

In affording the graduate these opportunities to be notified, fully involved in the process and to be heard, the university will be affording them the utmost opportunity to answer the adverse allegations against them before the serious and final decision as to whether to revoke their degree is made. This will ensure that all relevant facts, evidence and arguments are thoroughly tested, weighed and considered before a decision is made that may be of such significant detriment to the graduate. It will also prevent the graduate from arguing, for instance, that the inability to cross-examine witnesses was a breach of the hearing rule if they later

107 See, eg, Heatley v Tasmanian Racing and Gaming Commission (1977) 137 CLR 487.

108 See, eg, Re Macquarie University; Ex parte Ong (1989) 17 NSWLR 113.

109 Depending on the circumstances of the case, sometimes written submissions will be adequate for the applicant to answer any prejudicial allegations made against them, whereas in other cases a face-to-face hearing may be necessary: see, eg, Chen v Minister for Immigration and Ethnic Affairs (1994) 48 FCR 591, 602 (The Court).

110 Whether legal or other representation is required will depend on the circumstances of the case, including the seriousness of the allegations. See, eg, Krstic v Australian Telecommunications Commission (1988) 20 FCR 486. See also WABZ v Minister for Immigration and Multicultural and Indigenous Affairs (2004) 134 FCR 271, in which French and Lee JJ outlined the following factors to determine whether legal representation is required to give the applicant an adequate hearing, at 295:

The applicant's capacity to understand the nature of the proceedings and the issues for determination.

The applicant's ability to understand and communicate effectively in the language used by the Tribunal.

The legal and factual complexity of the case.

The importance of the decision to the applicant's liberty or welfare.

111 The ability to cross-examine witnesses is not usually required to satisfy the hearing rule provided that the applicant has an adequate opportunity to respond to adverse allegations upon which the decision will be based: see, eg, O'Rourke v Miller (1985) 156 CLR 342. In Hazan, one of the grounds argued by Hazan was that he had been denied natural justice because he had not been given the opportunity to crossexamine the principal of the Talmudical College who had corresponded with the University's solicitor to confirm that Hazan's 'progress ... attendance and conduct' at the Talmudical College was 'unsatisfactory': Hazan [1993] 1 VR 7, 13 (McCaughey). The Visitor did not consider this argument in detail, but stated that, '[t]he petitioner was afforded every opportunity to lead evidence before the committee of inquiry': at 12, which included Hazan being represented by legal counsel at the Committee's hearings. 
seek to challenge the revocation. Adherence to the above procedures should minimise legal challenges to a revocation decision or, if a legal challenge is made, increase the likelihood that a court will find in the university's favour.

\section{The Timing of the Revocation}

The conferral of a degree is a university's continued certification that a graduate has met the requirements of the degree, and such certification continues from the time it is conferred until its revocation. ${ }^{112}$ Thus, a university is obliged to revoke this certification at the time that it becomes aware of any misconduct justifying it, otherwise it may be acting illegally. ${ }^{113}$ It is therefore likely that a university will not lose the right to revoke a degree even though substantial time has passed between the conferral of the degree, and the discovery of the misconduct that is the basis for the revocation. Indeed, this is consistent with the approach taken by the United States courts. For example, in the case of Waliga, the errors in the transcripts of Waliga and Taylor were discovered some 15 years after Waliga and Taylor had graduated, and yet, this was not an issue of concern to the Supreme Court of Ohio when it determined that the Board of Trustees had the authority to revoke their degrees. Additionally, in Hand $v$ Matchett, ${ }^{114}$ the revocation of Hand's degree some five years after his graduation (during which time he had worked as a licensed psychologist), was not an issue for the Court of Appeals.

However, this does not mean that substantial time should pass between a university becoming aware of misconduct and acting upon it. Universities should commence the process of investigating the misconduct and instigating the procedural requirements to revoke the degree as soon as the alleged misconduct comes to its attention. Such timely action should avoid any argument from the graduate that the university has, by the passing of time, waived their right to exercise their statutory or implied power to revoke degrees. ${ }^{115}$

\section{The Degree Must Be Revoked by the Correct Body}

The issue of a degree needing to be revoked by a body or person having the authority to do so emerged as early as Bentley's Case in which it was held that the Vice Chancellor's Court did not have the power to revoke Bentley's degree. The Court stated that:

the suspension by the vice-chancellor's court is void, because it is set out in the return, that the chancellor, masters and scholars used to confer degrees, and to suspend them, and remove persons from them; so that the power of suspending degrees is in the whole body, but here the suspension was by the vice-chancellor's court, which is not the whole body, and that court has no power to suspend. ${ }^{116}$

112 Crookv Baker, 813 F 2d 88, 93 (Bailey Brown J) (6 ${ }^{\text {th }}$ Cir, 1987).

113 See comments of Cox J in Waliga v Board of Trustees at Kent State University, (Ohio Ct App, No 1444, 30 November 1984) slip opp 12.

114 Hand $v$ Matchett, 957 F 2 d 791 (10 $0^{\text {th }}$ Cir, 1992).

115 See, eg, Commonwealth of Australia v Verwayen (1990) 170 CLR 394.

116 Bentley's Case (1723) 2 Ld Raym 1334, 1341; 92 ER 370, 374-5. 
Instead, the revocation decision should have been made by those who could confer the degree, in this case the Chancellor, Masters and Scholars of the University as a collective body, not one of them acting alone.

This issue also arose in the United States case of Hand $v$ Matchett. When Hand challenged the revocation of his degree, the Court of Appeals upheld the challenge, finding that the revocation was invalid. This was because the determination to revoke Hand's degree was made by Matchett who was the Dean of the Graduate School instead of the body empowered to confer (and by implication, revoke) degrees, namely the Board of Regents. ${ }^{117}$ The Court also rejected the University's argument that the Board of Regents could validly delegate their degree-revoking power to Matchett by approving his degree revocation procedures as this was an effective abdication of this power. Barrett SCJ, who delivered the Court's judgment, stated:

The evidence is undisputed that with the exception of approving Dean Matchett's procedures for degree revocation, the Board of Regents had no involvement in the process. They delegated final authority to revoke the degree to a subordinate body in violation of New Mexico law. In order to come within the statute, it is necessary that the Board of Regents retain some involvement in the revocation process. They must exercise final authority. Because the Board of Regents did not exercise final authority in the decision to revoke Michael Hand's degree, the revocation is void. ${ }^{118}$

In an Australian context, if the decision to revoke a degree is made by a university body or committee that lacks the power to make such a decision under the university statute, this would amount to what is legally known as a 'jurisdictional error'. This is because the body or committee has made a decision that it is not empowered to make. ${ }^{119}$ Jurisdictional error is a recognised ground of judicial review, ${ }^{120}$ which a graduate could argue to challenge the decision.

Consequently, before revoking a degree, a university must specifically consider who, or which body, is legally authorised to revoke a degree. This will be a relatively simple consideration if there is an express provision about revocation in the university statute. For example, as set out above, section 10(3) of the La Trobe Act now expressly provides that, 'the Council may revoke any degree conferred or other award granted by the University'. ${ }^{121}$ However, when there is no express power to revoke in the university statute, universities must proceed with caution because there are a variety of persons who could plausibly attempt to revoke the degree. These include persons holding positions such as the Head of School or Faculty, the Academic Registrar, Vice Chancellor or

117 The Court commented that, '[t]he statute at issue gives the Board of Regents exclusive power to confer degrees. Conversely, it is appropriate to assume that to the extent a power to revoke degrees is recognized, it too is vested exclusively in the Regents': 957 F 2d 791, 795 (10 ${ }^{\text {th }}$ Cir, 1992).

118 Ibid 795-6.

119 Craig v South Australia (1995) 184 CLR 163.

120 See Administrative Decisions (Judicial Review) Act 1977 (Cth) s 5(1)(c); Administrative Decisions (Judicial Review) Act 1989 (ACT) s 5(1)(c); Judicial Review Act 1991 (Qld) s 20(2)(c); and Judicial Review Act 2000 (Tas) s17(2)(c). In the states and territories that do not have judicial review legislation, a graduate could still seek common law review of a decision to revoke their degree on the basis of jurisdictional error.

121 Emphasis added. 
Chancellor, or bodies such as the Academic Board, University Council, or a University Disciplinary Panel. If the statute is silent, the body that conferred the degree must be the one to revoke it. Further, the person or body empowered to revoke a degree should not delegate that power to another person or body within the university.

\section{CONCLUSION}

Although the revocation of degrees in Australia had been little heard of or considered until the MyMaster cheating scandal in 2015, universities undoubtedly have the power to revoke degrees. Revocation may become a more regular occurrence as universities seek to protect their reputations and the integrity of their degrees in an increasingly competitive educational marketplace. At the same time, graduates are likely to be more motivated to challenge the revocation of their degrees, given the significance of a degree, and the social, professional and economic detriment that they may face because of the revocation.

Universities can certainly employ more proactive measures to avoid having to revoke degrees in the first place. For example, universities can raise admission standards, provide additional support mechanisms for students who may be struggling under work and/or financial pressure, and educate students about misconduct and its serious consequences to deter them from committing it. ${ }^{122}$ Universities also have to be proactive about staff misconduct, privacy and data security to ensure that official student records are not improperly altered. However, universities are likely to be faced with difficult decisions about the revocation of their degrees in the future, and some of these decisions may be the subject of legal challenge. Given the severity of the consequences of a decision to revoke a degree to a graduate, and the accompanying cost, time and reputational damage that any legal challenge to such a decision may entail, a university will need to be mindful of the legalities surrounding revocation decisions. However, given the shortage of Australian case law in this area, many of the legal issues surrounding the revocation of degrees remain uncertain - it is hoped that this article will provide some guidance.

122 See, eg, Michelle Evans, 'Plagiarism and Academic Misconduct by Law Students: The Importance of Prevention Over Detection’ (2012) 17(2) International Journal of Law \& Education 99. 